\title{
The Tissue Distribution of Tumor Necrosis Factor Biosynthesis during Endotoxemia
}

\author{
Brett P. Giroir, John H. Johnson, Tracy Brown, Geoffrey L. Allen, and Bruce Beutler \\ The Howard Hughes Medical Institute and University of Texas Southwestern Medical Center, \\ Departments of Pediatrics and Internal Medicine, Dallas, Texas 75235
}

\begin{abstract}
Tumor necrosis factor (TNF) is a protein hormone implicated in the development of septic shock and other pathologic states. However, complexities inherent in detecting TNF synthesis by individual tissues have left the precise origins of this protein undefined. In addition, the possibility that localized TNF production may contribute to the pathogenesis of organ-specific diseases such as type I diabetes has not been explored in vivo. We have developed a transgenic mouse line bearing a reporter gene construct in which the TNF coding sequence and introns are replaced by a chloramphenicol acetyltransferase (CAT) coding sequence. In normal transgenic animals, CAT activity is expressed only in the thymus. When endotoxin is administered to the animals, CAT activity is also evident in kidney, heart, islets of Langerhans, spleen, lung, fallopian tubes, and uterus, but not in other organs. The biosynthesis of CAT in vivo correlated with tissue capacity to secrete TNF in vitro. Thus, TNF was secreted by all the tissues that expressed CAT, including lung, spleen, thymus, uterus / fallopian tubes, pancreatic islets, renal glomeruli, and cultured cardiac cells after exposure to endotoxin. (J. Clin. Invest. 1992. 90:693-698.) Key words: tumor necrosis factor • endotoxin • transgenic mice • septic shock
\end{abstract}

\section{Introduction}

Tumor necrosis factor (TNF) ${ }^{1}$ mediates diverse biological responses, including wasting in cancer (1-3) and shock during endotoxemia $(4,5)$. Intravenous administration of endotoxin to human volunteers causes a surge in serum TNF concentration, which is followed by elevations in heart rate, temperature, cortisol, and epinephrine (6). Administration of TNF to experimental animals mimics sepsis and multiorgan system failure (4). Apart from these studies, the involvement of TNF in disease in vivo has largely been investigated through the use of serum TNF assays (7-11), or through passive immunization experiments in which inhibition of specific effects of TNF are examined $(5,12-20)$.

Address correspondence to Bruce Beutler, M.D., Howard Hughes Medical Institute, U.T. Southwestern Medical Center, 5323 Harry Hines Blvd., Y5-210, Dallas, TX 75235-9050.

Received for publication 9 January 1992 and in revised form 10 April 1992.

1. Abbreviations used in this paper: CAT, chloramphenicol acetyltransferase; TNF, tumor necrosis factor.

J. Clin. Invest.

(c) The American Society for Clinical Investigation, Inc.

$0021-9738 / 92 / 09 / 0693 / 06 \$ 2.00$

Volume 90, September 1992, 693-698
Direct demonstration of TNF production by specific tissues has been more difficult. Since TNF biosynthesis is largely controlled at a translational level (21), detection of TNF mRNA in tissues may not indicate that synthesis of the protein has occurred. Because TNF is efficiently secreted from macrophages, immunocytochemical detection of the protein within these cells is generally difficult or impossible. These problems have caused a reliance upon serum TNF assays; however, it may be assumed that some or all of the TNF that is secreted may never reach the systemic circulation.

A typical problem in the detection of TNF biosynthesis in vivo concerns the islets of Langerhans and the potential role played by TNF in the pathogenesis of type I diabetes mellitus. It has been determined that TNF potentiates IL-1-induced pancreatic islet cell toxicity in vitro (22). Nonetheless, it is entirely unknown whether TNF is produced by islets in vivo, and whether such biosynthesis may be important in the development of insulitis preceding clinical diabetes.

To address problems like this one, we have developed transgenic mice bearing a reporter construct in which a chloramphenicol acetyltransferase (CAT) coding sequence is flanked by the mouse TNF promoter, 5'-untranslated region, and 3'untranslated region (23). This reporter construct mimicks the behavior of the authentic TNF gene in vitro, but yields a protein product (CAT) that is stable, nonsecreted, and that may be assayed with great sensitivity. Previously, studies on mice bearing the $\mathrm{CAT}_{\mathrm{TNF}}$ reporter have revealed the constitutive production of TNF by the thymus, implying a role for this cytokine in normal immunologic function or development (24). In this study, we describe the pattern of CAT biosynthesis in individual tissues following administration of endotoxin.

\section{Methods}

Animals. Transgenic mice bearing the $\mathrm{CAT}_{\mathrm{TNF}}$ reporter construct were produced as previously described (24), and maintained in an isolated animal colony at our institution. In this study, heterozygous progeny from a transgenic founder male and normal BALB/c females (Sasco, Omaha, NE) were used; animals were 8-12 wk of age at the time of investigation. Adult BALB/c females ( 8-12 wk) were used for experiments on TNF production in vitro, except for experiments using cardiac myocytes in which 1-d-old BALB/c pups were used. Adult WKY rats (Harlan Sprague Dawley, Inc., Indianapolis, IN) were used for the isolation of renal glomeruli and for the separation of pancreatic islets and acini.

CAT assay. The thin layer chromatography procedure of Gorman et al. (25) was used to measure CAT activity in cell lysates.

Induction of CAT biosynthesis in vivo. Heterozygous transgenics were injected intraperitoneally with $200 \mu \mathrm{g}$ of LPS ( $E$. coli strain O127:B8; Difco Laboratories, Inc., Detroit, MI). After the specified time, the animals were killed, their organs were incised and rinsed in saline, and then individually homogenized in a solution containing 1 $\mathrm{ml}$ of $0.3 \mathrm{M} \mathrm{NaCl}, 0.03 \mathrm{M} \mathrm{Na}_{3}$ citrate, and $0.4 \mathrm{M}$ tris pH 7.4 (homogenization buffer). Homogenates were then frozen by placing them on dry 
ice for $10 \mathrm{~min}$, and then thawed at room temperature. After centrifugation for $10 \mathrm{~min}$ at $16,000 \mathrm{~g}$, supernatant protein was quantitated and diluted to a concentration of $1 \mathrm{mg} / \mathrm{ml}$ in homogenization buffer. Samples were then heated to $65^{\circ} \mathrm{C}$ for $5 \mathrm{~min}$, centrifuged as before, and supernatants were collected. CAT assays were performed using $100 \mu \mathrm{l}$ of the supernatant so that each sample was derived from a homogenate containing $100 \mu \mathrm{g}$ of protein, except for samples containing the thymus or uterus and fallopian tubes, for which $20 \mu \mathrm{g}$ of protein was contained in the homogenate.

Pancreas. $18 \mathrm{~h}$ after intraperitoneal challenge with LPS (200 $\mu \mathrm{g})$, pancreatic islets and acini were isolated from four transgenic mice as previously described (26). After separation, islets and acini were gently resuspended in $200 \mu \mathrm{l}$ of homogenization buffer and placed on dry ice for $10 \mathrm{~min}$. CAT assays were performed on samples derived from homogenates containing $20 \mu \mathrm{g}$ of protein.

Production of TNF by organs in vitro. 8-wk-old BALB/c females were injected with LPS ( $200 \mu \mathrm{g}$ i.p.). After $30 \mathrm{~min}$, animals were killed by $\mathrm{CO}_{2}$ narcosis, and organs were excised. Whole single organs (except for liver, in which case only the left lobe was used) were minced in $2 \mathrm{ml}$ of DME, then incubated with LPS $(1 \mu \mathrm{g} / \mathrm{ml})$ for $4 \mathrm{~h}$ at $37^{\circ} \mathrm{C}$. Control organs were not exposed to LPS either in vivo or in vitro. Medium was then harvested and assayed for TNF activity as previously described (27). Cytotoxicity was assessed by staining the residual cells with crystal violet, and interpreted with reference to a standard preparation of recombinant human TNF. Cytotoxicity was neutralized in each case to assure specificity by preincubation with a TNF receptor-IgG chimeric protein as previously described (28).

Kidney. Because procedures for isolation of highly purified glomeruli from the rat have previously been described (29), two WKY rats were killed and their kidneys were removed. Glomeruli, essentially devoid of tubular contaminants, were isolated and then incubated for 4 $h$ in DME containing 5\% FCS (Gibco Laboratories, Grand Island, NY) with or without LPS $(1 \mu \mathrm{g} / \mathrm{ml})$. Medium was then harvested and assayed for TNF as described above.

Pancreas. Because cannulation of the common bile duct is accomplished more readily in rats than in mice, normal adult WKY rats were used for the isolation of islets to be assayed for TNF secretion. Pancreatic islets and acini were isolated from two rats, washed twice in DME, then incubated for $4 \mathrm{~h}$ in DME containing 5\% FCS, with or without LPS $(1 \mu \mathrm{g} / \mathrm{ml})$. Medium was then harvested and assayed for TNF as described above.

Heart. Cardiac cells were isolated by a modification of an earlier protocol (30). Briefly, the heart was removed from a newborn mouse, incised, and rinsed thoroughly in cold Hanks' balanced salt solution (Gibco). The myocardium was finely minced and allowed to incubate in trypsin ( $0.05 \%)$-EDTA (Gibco) at $37^{\circ} \mathrm{C}$ for $10 \mathrm{~min}$, and then centrifuged for $5 \mathrm{~min}$ at $800 \mathrm{~g}$. The incubation was repeated until no myocardium remained visible at a macroscopic level. The preparation was then washed twice in DME containing $10 \%$ FCS, divided in half, and incubated for $12 \mathrm{~h}$ at $37^{\circ} \mathrm{C}$. Penicillin and streptomycin solution (Gibco) was added to a final concentration of $4 \%$. Following incubation, medium was removed, and wells were washed with prewarmed DME containing $10 \%$ FCS to remove any remaining nonadherent cells. Cells were then incubated in DME containing 10\% FCS either with or without LPS $(1 \mu \mathrm{g} / \mathrm{ml})$. After $4 \mathrm{~h}$, medium was harvested and TNF was assayed as described above.

\section{Results}

Intraperitoneal administration of LPS induced tissue-specific synthesis of CAT in transgenic mice heterozygous for the CAT $_{\text {TNF }}$ reporter. Before LPS administration, CAT is synthesized only in the thymus, reflecting biosynthesis of TNF in this organ under normal conditions (24). $4 \mathrm{~h}$ after LPS challenge, however, reporter gene induction is indicated by CAT activity

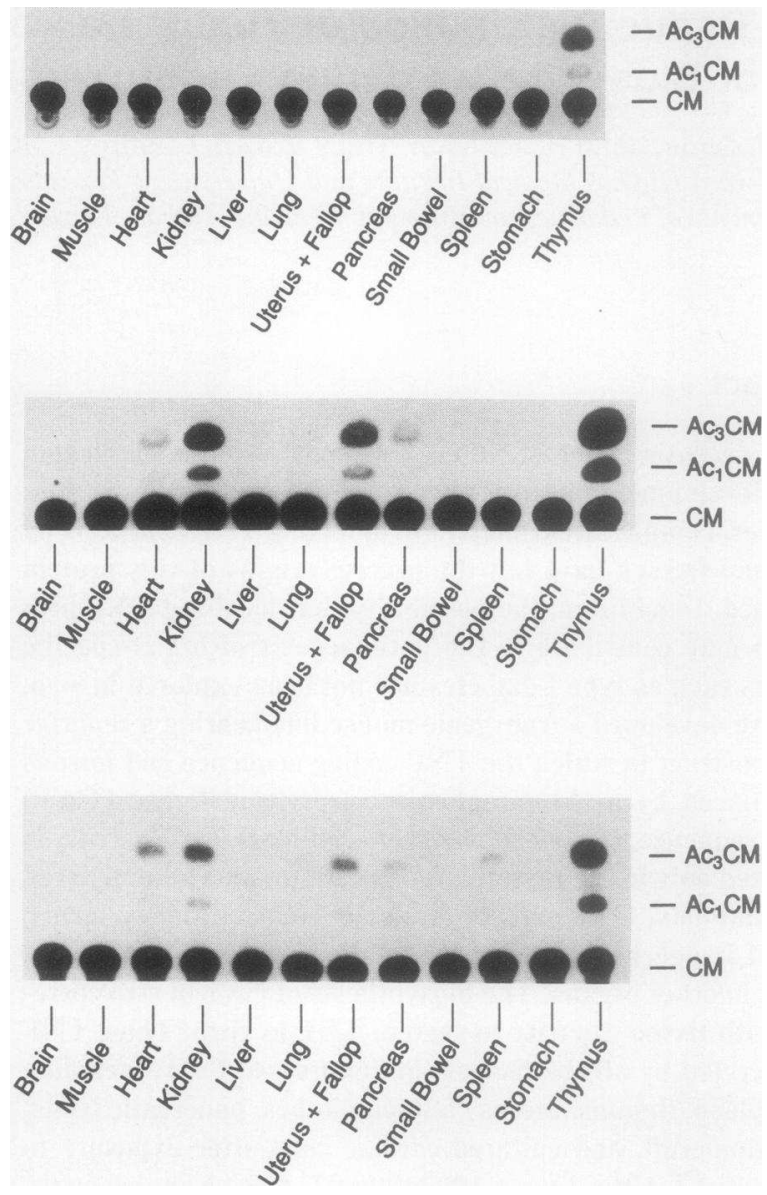

Figure 1. $\mathrm{CAT}_{\mathrm{TNF}}$ biosynthesis by tissues in transgenic mice following intraperitoneal endotoxin administration $(a)$ prior to endotoxin; $(b)$ $4 \mathrm{~h}$ after endotoxin; and (c) $24 \mathrm{~h}$ after endotoxin. $C M$ is nonacetylated chloramphenicol; $A c_{1} C M$ and $A c_{3} C M$ are the one- and threeacetylated form of chloramphenicol, respectively, produced by CAT. Assays were performed on $100 \mu \mathrm{g}$ of protein extract from each tissue, except as otherwise noted in the text.

in the kidney, uterus/fallopian tubes, lung, pancreas, heart, and spleen (Fig. 1). The uterus and the fallopian tube each synthesized CAT individually, but were assayed together for the purposes of this study. The highest levels of LPS-induced CAT biosynthesis per milligram of tissue were found in the kidney and uterus/fallopian tubes. A similar pattern of CAT activation was present $24 \mathrm{~h}$ after the initial LPS challenge, except for relatively higher CAT activity in the spleen. No CAT activity could be demonstrated in brain, skeletal muscle, liver, small bowel, or stomach at either time point. Furthermore, no CAT activity could be demonstrated at either time in urine obtained by bladder puncture or in the vas deferens (not shown).

To determine whether CAT production in the pancreas could be localized to either the exocrine or endocrine structures, four transgenic mice were injected intraperitoneally with endotoxin $18 \mathrm{~h}$ before death. The pancreases were removed, and intact islets were separated from pancreatic acini and assayed for CAT activity. Such studies revealed that CAT biosynthesis occurred primarily, if not exclusively, in the pancreatic islets (Fig. 2). 


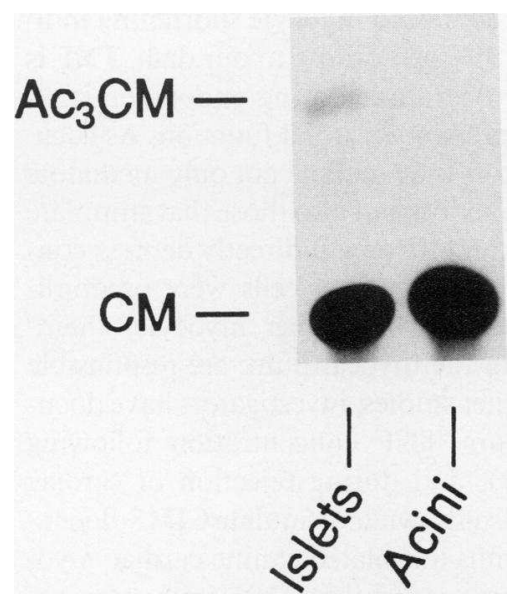

Figure 2. $\mathrm{CAT}_{\mathrm{TNF}}$ biosynthesis by pancreatic islets following intraperitoneal endotoxin. CAT assays were performed on $20 \mu \mathrm{g}$ of protein from acini or islets. CAT activity is displayed as before.

Next, we wished to verify that the TNF molecule itself could be synthesized by each tissue or tissue component which was shown to synthesize CAT. After $4 \mathrm{~h}$ in culture with endotoxin containing medium, TNF was detected in the supernatant from cultures containing minced lung, spleen, thymus, uterus/fallopian tubes, and to a lesser extent, liver and brain (Fig. 3). Although CAT biosynthesis occurred in kidney as noted above, TNF was not detectable in media from minced cultured preparations of this organ. When exogenous TNF was added to minced normal kidney, however, TNF activity rapidly disappeared from the medium, suggesting binding or inactivation of TNF (data not shown). Therefore, glomeruli were separated from other renal structures, and stimulated with LPS in vitro. TNF secreted by glomeruli was readily detectable after induction by LPS.

Although CAT activity was present in the myocardium following endotoxemia in vivo, minced heart did not secrete detectable TNF. However, when single cell suspensions of cardiac cells were allowed to adhere to plastic and grow in primary culture, cardiac cells did secrete TNF upon exposure to LPS (Fig. 4). Since CAT biosynthesis in the pancreas was localized to the islets, acini and islets were separated and each assayed for TNF production after LPS exposure in vitro. Fig. 5 illustrates that CAT biosynthesis by islets in vivo is reflected by TNF secretion by islets in vitro. No TNF was detected in culture medium from pancreatic acini challenged with endotoxin.

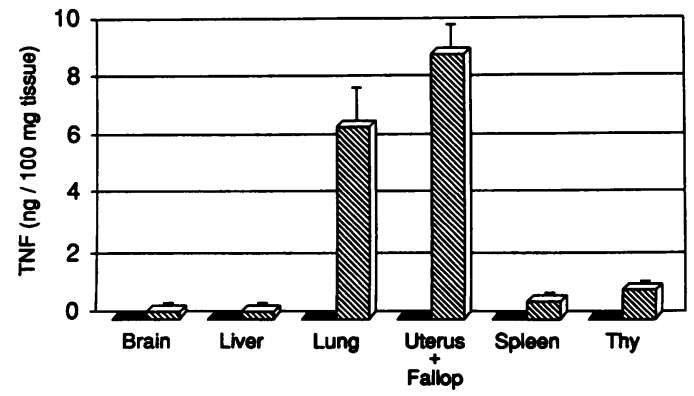

Figure 3. TNF synthesis by whole organ suspensions after LPS challenge in vitro. Solid bars denote spontaneous TNF secretion in the absence of LPS. Hatched bars denote TNF secretion following LPS stimulation. TNF levels are displayed per $100 \mathrm{mg}$ of tissue. Error bars represent the standard deviation of repeated TNF bioassays ( $n$ $=4)$.

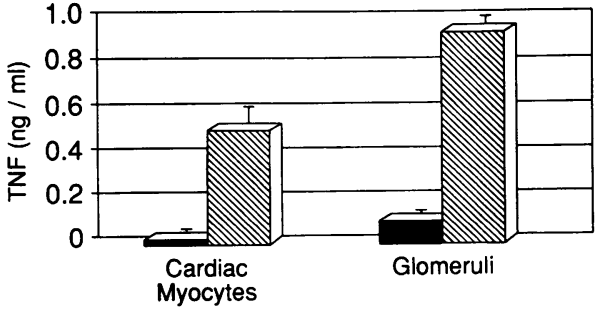

Figure 4. TNF synthesis by cardiac cells and glomeruli in vitro. Black bars denote spontaneous secretion of TNF in the absence of LPS. Hatched bars denote TNF secretion following LPS stimulation. Error bars represent the standard deviation of repeated TNF bioassays ( $n$ $=4$ ).

\section{Discussion}

Although a variety of cell types have been shown to secrete TNF under experimental conditions in vitro, the tissue origins of this protein in vivo and the relative contribution of each tissue to total TNF production have not previously been determined. Furthermore, the lack of a sensitive tissue-specific assay for this cytokine precludes further investigation of its role in many disease models.

Other investigators have attempted to examine the tissue origins of TNF, but with only limited success. Ulich and coworkers failed to detect endotoxin-induced increases in TNF mRNA levels in spleen, liver, or small bowel despite marked elevation in serum TNF levels (31); these investigators had previously demonstrated only minor increases in TNF mRNA in kidney under such conditions (32). These results are consistent with the fact that the biosynthesis of TNF is largely regulated translationally (21), and with the fact that TNF mRNA is constitutively expressed by a variety of tissues (33). Other approaches, including immunohistochemical detection of TNF, have also been difficult because TNF is transiently synthesized following stimulation by LPS and because it is effeciently secreted from the cell of origin once synthesized (Beutler, B., unpublished data).

To address these problems and to allow more sensitive determination of TNF synthesis in various diseases, we have designed a CAT reporter flanked by the known TNF regulatory sequences to mimic TNF biosynthesis in transgenic mice in vivo. In earlier studies we demonstrated that the $\mathrm{CAT}_{\mathrm{TNF}}$ reporter indicates TNF biosynthesis when stably transfected into macrophage cell lines in vitro (23), and was silent (though potentially activable [34]) in cell types that were unable to

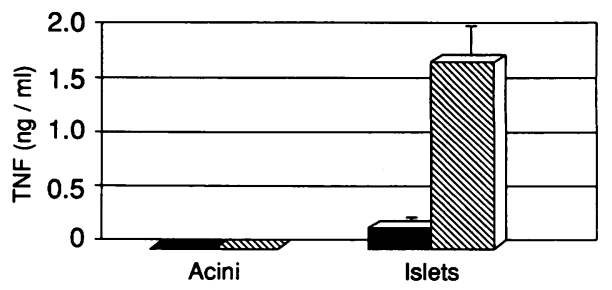

Figure 5. TNF synthesis by isolated rat islets in vitro. Black bars denote spontaneous secretion of TNF in the absence of LPS. Hatched bars denote TNF secretion following LPS stimulation. Error bars represent the standard deviation of repeated TNF bioassays $(n=4)$. 
secrete TNF. Next, we demonstrated that transgenic mice bearing this construct manifested LPS-inducible CAT biosynthesis in cultured peritoneal macrophages. In these animals, CAT was constitutively expressed in the thymus, which led to the observation that TNF is itself constitutively secreted by thymocytes in vitro (24). These observations suggested that the pattern of CAT biosynthesis observed in transgenic mice in pathological states would accurately reflect the pattern of TNF biosynthesis in vivo. During endotoxemia, CAT is synthesized in the kidney, heart, lung, pancreas, uterus/fallopian tubes, and spleen. As we have demonstrated here, each of these tissues has the capacity to secrete TNF itself after stimulation with endotoxin in vitro. Synthesis of TNF by the pancreas has not previously been described. Our results suggest that the pancreas participates in TNF production during sepsis, and that the islets are predominantly responsible for such synthesis. Other workers have demonstrated that TNF potentiates IL-1-mediated islet cytotoxicity in vitro $(22,35,36)$. TNF also enhances interferon-induced HLA class II expression on islet cells, and thus may contribute to autoimmune destruction of the islet (37). TNF has further been shown to up-regulate IL-6 production by pancreatic islet cells (38); this IL-6 production by beta cells may itself be of pathogenetic importance, since administration of antibodies directed against IL-6 protects against the development of insulitis, beta cell destruction, and the development of diabetes (39). Other investigators have claimed that a possible source of TNF within the islet is invading lymphocytes during insulitis, since these lymphocytes were found to contain TNF mRNA. However, translation of the TNF message was never demonstrated (40). The transgenic model presented here suggests that TNF is produced within the islet itself in response to a systemic stimulus. This conclusion is supported by the finding that TNF is secreted by isolated normal islets in vitro. Thus, TNF biosynthesis within the islet does not depend on the presence of an inflammatory infiltrate. Whether such TNF production within the islet is involved in the pathogenesis of insulitis and whether it affects beta cell survival remain to be determined.

The kidneys, which are frequently damaged during septic shock, appear to be a major source of TNF during endotoxemia. TNF originating in the kidney may gain access to the circulation and contribute to the systemic manifestations of sepsis (41); alternatively, TNF of glomerular origin may act within the kidney and impair filtration or tubular function. Other workers have shown that isolated glomerular mesangial cells, a fraction of which are bone marrow-derived, have the capacity to secrete TNF in response to LPS in vitro (42). In addition, the membrane-bound $26-\mathrm{kD}$ form of TNF is detectable on the surface of cultured proximal tubular cells after incubation with endotoxin (43). TNF mRNA accumulation has also been documented in the glomeruli of mice with lupus nephritis (44). Thus, the expression of TNF by the kidney in endotoxemic animals is consistent with previous data, suggesting that this organ is able to synthesize the protein.

During these studies, CAT biosynthesis was also detected within the myocardium during endotoxemia. The sepsis syndrome in humans is characterized by profound, reversible myocardial dysfunction that, at least in part, is mediated by circulating myocardial depressant factor(s) (45-48). TNF was recently shown to be a depressant factor, since infusion of dogs with this cytokine causes cardiovascular changes similar to those observed in sepsis (41). Furthermore, among IL-1, IL-2,
LPS, and TNF, only TNF depressed myocyte shortening indices when assayed in vitro (49). According to our data, TNF is synthesized within the myocardium during endotoxemia. It may thus act locally to depress myocardial function. As such, myocardial depressant factors may include not only mediators that acutely alter cardiac function, but also those that stimulate myocardial TNF synthesis and thereby indirectly depress contractility. Although the isolated cardiac cells were predominantly myocytes, it is not known whether myocytes themselves, or other cell types in the myocardium, are responsible for TNF biosynthesis. In other studies, investigators have documented elevations in serum TNF concentration following myocardial infarction (50), and during rejection of cardiac allografts (51). TNF was also shown to stimulate CD18-dependent adherence of neutrophils to isolated canine cardiac myocytes in vitro (52). Our data suggest that TNF production occurs within the myocardium itself, where it may exacerbate contractile dysfunction or myocardial neutrophil accumulation following injury.

Tabor and co-workers have demonstrated that TNF, along with other monokines, is secreted by alveolar macrophages after endotoxin exposure (53). It is also known that infusion of TNF into animals leads to a pulmonary syndrome similar to human adult respiratory distress syndrome $(54,55)$. However, the production of TNF by the lung displays compartmentalization; i.e., intravenous endotoxin does not stimulate intrapulmonary TNF secretion in rodents (56) or humans (57), whereas intrapulmonary endotoxin instillation causes pronounced TNF secretion by the lung. The data from transgenic animals are consistent with these findings, in that CAT activity is only minimally induced in the lung during endotoxemia. In addition to pulmonary TNF production, our model suggests that cells within the uterus/fallopian tubes also synthesize TNF. Previous work has demonstrated that isolated uterine decidua secretes TNF upon stimulation with LPS in vitro (58).

The brain and liver secrete minimally detectable quantities of TNF in vitro after exposure to LPS. CAT activity is undetectable in these organs following administration of LPS to transgenic animals. It is likely that the lack of CAT biosynthesis during endotoxemia reflects an intact blood-brain barrier which prevents central nervous system cell activation in the absence of meningeal infection (59-62). Although Kuppfer cells may secrete relatively small quantities of TNF in vitro and have been identified as a site of TNF production in vivo (63), our model suggests that the liver is not a principal source of TNF during endotoxemia of intraperitoneal origin. These data do not preclude the possibility that liver may be an important source of TNF production in other pathologic conditions; e.g., during hepatic allograft rejection (64) or ischemia followed by reperfusion $(65,66)$.

The use of transgenic mice bearing a reporter construct for TNF biosynthesis has provided insight into the contributions of diverse tissues to TNF synthesis both in disease and in health. Such animals may now be used to examine a variety of conditions in which TNF production may be of pathogenic importance.

\section{Acknowledgments}

Dr. B. P. Giroir is a fellow of the Pediatric Scientist Development Program supported by National Institute of Child Health and Human Development grant HD-22297. 


\section{References}

1. Oliff, A., D. Defeo-Jones, M. Boyer, D. Martinez, D. Kiefer, G. Vuocolo, A Wolfe, and S. H. Socher. 1987. Tumors secreting human TNF/cachectin induce cachexia in mice. Cell. 50:555-563.

2. Cerami, A., Y. Ikeda, N. Le Trang, P. J. Hotez, and B. Beutler. 1985. Weight loss associated with an endotoxin-induced mediator from peritoneal macrophages: the role of cachectin (tumor necrosis factor). Immunol. Lett. 11:173177.

3. Sherry, B. A., J. Gelin, Y. Fong, M. Marano, H. Wei, A. Cerami, S. F Lowry, K. G. Lundholm, and L. L. Moldawer. 1989. Anticachectin/tumor necrosis factor-alpha antibodies attenuate development of cachexia in tumor models. FASEB (Fed. Am. Soc. Exp. Biol.) J. 3:1956-1962.

4. Tracey, K. J., B. Beutler, S. F. Lowry, J. Merryweather, S. Wolpe, I. W. Milsark, R. J. Hariri, T. J. Fahey, III, A. Zentella, J. D. Albert, et al. 1986. Shock and tissue injury induced by recombinant human cachectin. Science (Wash. DC). 234:470-474

5. Beutler, B., I. W. Milsark, and A. Cerami. 1985. Passive immunization against cachectin/tumor necrosis factor (TNF) protects mice from the letha effect of endotoxin. Science (Wash. DC). 229:869-871.

6. Michie, H. R., K. R. Manogue, D. R. Spriggs, A. Revhaug, S. O’Dwyer, C. A. Dinarello, A. Cerami, S. M. Wolff, and D. W. Wilmore. 1988. Detection of circulating tumor necrosis factor after endotoxin administration. $N$. Engl. J. Med. 318:1481-1486.

7. Girardin, E., G. E. Grau, J.-M. Dayer, P. Roux-Lombard, and P.-H. Lambert. 1988. Tumor necrosis factor and interleukin-1 in the serum of children with severe infectious purpura. N. Engl. J. Med. 319:397-400.

8. Damas, P., A. Reuter, P. Gysen, J. Demonty, M. Lamy, and P. Franchimont. 1989. Tumor necrosis factor and interleukin-1 serum levels during severe sepsis in humans. Crit. Care Med. 17:975-978.

9. Waage, A., A. Halstensen, and T. Espevik. 1987. Association between tumour necrosis factor in serum and fatal outcome in patients with meningococcal disease. Lancet. i:8529:355-357.

10. Grau, G. E., T. E. Taylor, M. E. Molyneux, J. J. Wirima, P. Vassalli, M. Hommel, and P-H. Lambert. 1989. Tumor necrosis factor and disease severity in children with falciparum malaria. N. Engl. J. Med. 320:1586-1591.

11. Marks, J. D., C. B. Marks, J. M. Luce, A. B. Montgomery, J. Turner, C. A Metz, and J. F. Murray. 1990. Plasma tumor necrosis factor in patients with septic shock: Mortality rate, incidence of adult respiratory distress syndrome, and effects of methylprednisolone administration. Am. Res. Respir. Dis. 141:94-97.

12. Mathison, J. C., E. Wolfson, and R. J. Ulevitch. 1988. Participation of tumor necrosis factor in the mediation of gram negative bacterial lipopolysaccharide-induced injury in rabbits. J. Clin. Invest. 81:1925-1937.

13. Tracey, K. J., Y. Fong, D. G. Hesse, K. R. Manogue, A. T. Lee, G. C. Kuo, S. F. Lowry, and A. Cerami. 1987. Anti-cachectin/TNF monoclonal antibodies prevent septic shock during lethal bacteraemia. Nature (Lond.). 330:662-666.

14. Chang, H. R., G. E. Grau, and J. C. Pechère. 1990. Role of TNF and IL-1 in infections with Toxoplasma gondii. Immunology. 69:33-37.

15. Piguet, P. F., M. A. Collart, G. E. Grau, A.-P. Sappino, and P. Vassalli. 1990. Requirement of tumour necrosis factor for development of silica-induced pulmonary fibrosis. Nature (Lond.). 344:245-247.

16. Kindler, V., A-P. Sappino, G. E. Grau, P-F. Piguet, and P. Vassalli. 1989 The inducing role of tumor necrosis factor in the development of bactericidal granulomas during BCG infection. Cell. 56:731-740.

17. Piguet, P. F., M. A. Collart, G. E. Grau, Y. Kapanci, and P. Vassalli. 1989 Tumor necrosis factor/cachectin plays a key role in induced pneumopathy and fibrosis. J. Exp. Med. 170:655-664.

18. Grau, G. E., L. F. Fajardo, P-F. Piguet, B. Allet, P-H. Lambert, and P. Vassalli. 1987. Tumor necrosis factor (cachectin) as an essential mediator in murine cerebral malaria. Science (Lond.). 237:1210-1212.

19. Piguet, P-F., G. E. Grau, B. Allet, and P. Vassalli. 1987. Tumor necrosis factor/cachectin is an effector of skin and gut lesions of the acute phase of graftvs-host disease. J. Exp. Med. 166:1280-1289.

20. Piguet, P. F., G. Grau, B. Allet, and P. Vassalli. 1987. Tumor necrosis factor (TNF) is an important mediator of the mortality and morbidity induced by the graft-versus-host reaction (GVHR). Immunobiology. 175:27. (Abstr.)

21. Han, J., T. Brown, and B. Beutler. 1990. Endotoxin-responsive sequences control cachectin/TNF biosynthesis at the translational level. J. Exp. Med. 171:465-475.

22. Eizirik, D. L. 1988. Interleukin-1 induced impairment in pancreatic islet oxidative metabolism of glucose is potentiated by tumor necrosis factor. Acta Endocrinol. (Copenh). 119:321-325.

23. Beutler, B., and T. Brown. 1991. A CAT reporter construct allows ultrasensitive estimation of TNF synthesis, and suggests that the TNF gene has been silenced in non-macrophage cell lines. J. Clin. Invest. 87:1336-1344.

24. Giroir, B. P., T. Brown, and B. Beutler. 1992. Constitutive synthesis of tumor necrosis factor in the thymus. Proc. Natl. Acad. Sci. USA. 89:4864-4868.

25. Gorman, C. M., L. F. Moffat, and B. H. Howard. 1982. Recombinant genomes which express chloramphenicol acetyltransferase in mammalian cells. Mol. Cell. Biol. 2:1044-1051.
26. Johnson, J. H., B. P. Crider, K. McCorkle, M. Alford, and R. H. Unger. 1990. Inhibition of glucose transport into rat islet cells by immunoglobulins from patients with new-onset insulin-dependent diabetes mellitus. N. Engl. J. Med. 322:653-659.

27. Cseh, K., and B. Beutler. 1989. Alternative cleavage of the cachectin/TNF propeptide results in a larger, inactive form of secreted protein. J. Biol. Chem. 264:16256-16260

28. Peppel, K., D. Crawford, and B. Beutler. 1991. A tumor necrosis factor (TNF) receptor-IgG heavy chain chimeric protein as a bivalent antagonist of TNF activity. J. Exp. Med. 174:1483-1489.

29. Fong, J. S. C., and K. N. Drummond. 1968. Method for preparation of glomeruli for metabolic studies. J. Lab. Clin. Med. 71:1031-1039.

30. Harary, I., and B. Farley. 1991. In vitro studies of single isolated beating heart cells. Science (Wash. DC). 131:1674-1675.

31. Ulich, T. R., K. Guo, B. Irwin, D. G. Remick, and G. N. Davatelis. 1990. Endotoxin-induced cytokine gene expression in vivo. II. Regulation of tumor necrosis factor and interleukin-1alpha/beta expression and suppression. Am. J. Pathol. 137:1173-1185.

32. Ulich, T. R., K. Guo, and J. D. Castillo. 1989. Endotoxin-induced cytokine gene expression in vivo. I. Expression of tumor necrosis factor mRNA in visceral organs under physiologic conditions and during endotoxemia. Am. J. Pathol. 134:11-14.

33. Tovey, M. G., J. Content, I. Gresser, J. Gugenheim, B. Blanchard, J. Guymarho, P. Poupart, M. Gigou, A. Shaw, and W. Fiers. 1988. Genes for IFNbeta-2 (IL-6), tumor necrosis factor, and IL-1 are expressed at high levels in the organs of normal individuals. J. Immunol. 141:3106-3110.

34. Kruys, V., K. Kemmer, A. Shakhov, V. Jongeneel, and B. Beutler. 1992. Constitutive activity of the TNF promoter is canceled by the $3^{\prime}$ untranslated region in non-macrophage cell lines; a transdominant factor overcomes this suppressive effect. Proc. Natl. Acad. Sci. USA. 89:673-677.

35. Mandrup-Poulsen, T., K. Bendtzen, J. Nerup, C. A. Dinarello, M. Svenson, and J. H. Nielsen. 1986. Affinity-purified human interleukin-1 is cytotoxic to isolated islets of Langerhans. Diabetes. 29:63-67.

36. Bendtzen, K., T. Mandrup-Poulsen, J. Nerup, J. H. Nielsen, C. A. Dinarello, and M. Svenson. 1987. Cytotoxicity of human pl7 interleukin-1 for pancreatic islets of Langerhans. Science (Wash. DC). 232:1545-1547.

37. Wright, Jr., J. R., H. R. Epstein, V. Hauptfeld, and P. E. Lacy. 1988. Tumor necrosis factor enhances interferon-induced Ia antigen expression on murine islet parenchymal cells. Am. J. Pathol. 130:427-430.

38. Campbell, I. L., A. Cutri, A. Wilson, and L. C. Harrison. 1989. Evidence for IL-6 production by and effects on the pancreatic beta-cell. J. Immunol. 143:1188-1191.

39. Campbell, I. L., T. W. H. Kay, L. Oxbrow, and L. C. Harrison. 1991. Essential role for interferon-gamma and interleukin-6 in autoimmune insulin-dependent diabetes in NOD/Wehi mice. J. Clin. Invest. 87:739-742.

40. Held, W., H. R. MacDonald, I. L. Weissman, M. W. Hess, and C. Mueller. 1990. Genes encoding tumor necrosis factor $\alpha$ and granzyme A are expressed during development of autoimmune diabetes. Proc. Natl. Acad. Sci. USA. 87:2239-2243.

41. Natanson, C., P. W. Eichenholz, R. L. Danner, P. Q., Eichacker, W. D. Hoffman, G. C. Kuo, S. M. Banks, T. J. MacVittie, and J. E. Parrillo. 1989. Endotoxin and tumor necrosis factor challenges in dogs simulate the cardiovascular profile of human septic shock. J. Exp. Med. 169:823-832.

42. Baud, L., J-P. Oudinet, M. Bens, L. Noe, M-N. Peraldi, E. Rondeau, J. Etienne, and R. Ardaillou. 1989. Production of tumor necrosis factor by rat mesangial cells in response to bacterial lipopolysaccharide. Kidney Int. 35:11111118.

43. Jevnikar, A. M., R. P. Wuthrich, D. C. Brennan, W. Maslinski, L. H. Glimcher, and V. E. Rubin-Kelley. 1991. TNF-alpha is expressed on the surface of kidney proximal tubular cells. Transplant. Proc. 23:231-232.

44. Boswell, J. M., M. A. Yui, D. W. Burt, and V. E. Kelley. 1988. Increased tumor necrosis factor and IL-1 $\beta$ gene expression in the kidneys of mice with lupus nephritis. J. Immunol. 141:3050-3054.

45. Parrillo, J. E., C. Burch, J. H. Shelhamer, M. M. Parker, C. Natanson, and W. Schuette. 1985. A circulating myocardial depressant substance in humans with septic shock. J. Clin. Invest. 76:1539-1553.

46. Parrillo, J. E., M. M. Parker, C. Natanson, A. F. Suffredini, R. L. Danner, R. E. Cunnion, and F. P. Ognibene. 1990. Septic shock in humans. Advances in the understanding of pathogenesis, cardiovascular dysfunction, and therapy. Ann. Intern. Med. 113:227-242.

47. Dhainaut, J. F., J. J. Lanore, J. M. de Gournay, M. F. Huyghebaert, F. Brunet, D. Villemant, and J. F. Monsallier. 1988. Right ventricular dysfunction in patients with septic shock. Intensive Care Med. 14:488-491.

48. Reilly, J. M., R. E. Cunnion, C. Burch-Whitman, M. M. Parker, J. H. Shelhamer, and J. E. Parrillo. 1989. A circulating myocardial depressant substance is associated with cardiac dysfunction and peripheral hypoperfusion (lactic acidemia) in patients with septic shock. Chest. 95:1072-1080

49. Hollenberg, S. M., R. E. Cunnion, M. Lawrence, J. L. Kelley, and J. E. Parrillo. 1989. Tumor necrosis factor depresses myocardial cell function: results using an in vitro assay of myocyte performance. Clin. Res. 37:528A. 
50. Maury, C. P. J., and A-M. Teppo. 1989. Circulating tumor necrosis factoralpha (cachectin) in myocardial infarction. J. Intern. Med. 225:333-336.

51. Chollet-Martin, S., J. P. Depoix, U. Hvass, Y. Pansard, C. Vissuzaine, and M. A. Gougerot-Pocidalo. 1990. Raised plasma levels of tumor necrosis factor in heart allograft rejection. Transplant. Proc. 22:283-286.

52. Entman, M. L., K. Youker, S. B. Shappell, C. Siegel, R. Rothlein, W. J. Dreyer, F. C. Schmalstieg, and C. W. Smith. 1990. Neutrophil adherence to isolated adult canine myocytes. Evidence for a CD18-dependent mechanism. $J$. Clin. Invest. 85:1497-1506.

53. Tabor, D. R., S. K. Burchett, and R. F. Jacobs. 1988. Enhanced production of monokines by canine alveolar macrophages in response to endotoxin-induced shock (42681). Proc. Soc. Exp. Biol. Med. 187:408-415.

54. Horvath, C. J., T. J. Ferro, G. Jesmok, and A. B. Malik. 1988. Recombinant tumor necrosis factor increases pulmonary vascular permeability independent of neutrophils. Proc. Natl. Acad. Sci. USA. 85:9219-9223.

55. Lilly, C. M., J. S. Sandhu, A. Ishizaka, H. Harada, M. Yonemaru, J. W. Larrick, T-X. Shi, P. T. O'Hanley, and T. A. Raffin. 1989. Pentoxifylline prevents tumor necrosis factor-induced lung injury. Am. Rev. Respir. Dis. 139:1361-1368.

56. Nelson, S., G. J. Bagby, B. G. Bainton, L. A. Wilson, J. J. Thompson, and W. R. Summer. 1989. Compartmentalization of intraalveolar and systemic lipopolysaccharide-induced tumor necrosis factor and the pulmonary inflammatory response. J. Infect. Dis. 159:189-194.

57. Boujoukos, A. J., G. D. Martich, E. Supinski, and A. F. Suffredini. 1992. Compartmentalization of acute cytokine responses in humans after intravenous endotoxin administration: characteristics of bronchoalveolar lavage cytokine mRNA and protein. Am. Rev. Respir. Dis. 145:A441. (Abstr.)

58. Casey, M. L., S. M. Cox, B. Beutler, L. Milewich, and P. C. MacDonald. 1989. Cachectin/tumor necrosis factor-alpha formation in human decidua. Potential role of cytokines in infection-induced preterm labor. J. Clin. Invest. 83:430-436.

59. Mustafa, M. M., M. H. Lebel, O. Ramilo, K. D. Olsen, J. S. Reisch, B. Beutler, and G. H. McCracken, Jr. 1989. Correlation of interleukin-lbeta and cachectin concentrations in cerebrospinal fluid and outcome from bacterial meningitis. J Pediatr. 115:208-213.

60. Ramilo, O., M. M. Mustafa, J. Porter, X. Sáez-Llorens, J. Mertsola, K. D. Olsen, J. P. Luby, B. Beutler, and G. H. McCracken, Jr. 1990. Detection of interleukin $1 \beta$ but not tumor necrosis factor- $\alpha$ in cerebrospinal fluid of children with aseptic meningitis. Am. J. Dis. Child. 144:349-352.

61. Mustafa, M. M., O. Ramilo, X. Sáez-Llorens, J. Mertsola, and G. H. McCracken, Jr. 1989. Role of tumor necrosis factor alpha (cachectin) in experimental and clinical bacterial meningitis. Pediatr. Infect. Dis. J. 8:907-908.

62. Mustafa, M. M., O. Ramilo, X. Sáez-Llorens, J. Mertsola, R. R. Magness, and G. H. McCracken, Jr. 1989. Prostaglandins $E_{2}$ and $I_{2}$, interleukin 1-beta, and tumor necrosis factor in cerebrospinal fluid of infants and children with bacterial meningitis. Pediatr. Infect. Dis. J. 8:921-922.

63. Chensue, S. W., P. D. Terebuh, D. G. Remick, W. E. Scales, and S. L. Kunkel. 1991. In vivo biologic and immunohistochemical analysis of interleukin-1 alpha, beta and tumor necrosis factor during experimental endotoxemia. Am. J. Pathol. 138:395-402.

64. Imagawa, D. K., J. M. Millis, K. M. Olthoff, L. J. Derus, D. Chia, L. R. Sugich, M. Ozawa, R. A. Dempsey, Y. Iwaki, P. J. Levy, et al. 1990. The role of tumor necrosis factor in allograft rejection. I. Evidence that elevated levels of tumor necrosis factor-alpha predict rejection following orthotopic liver transplantation. Transplantation (Baltimore). 50:219-225.

65. Colletti, L. M., G. D. Burtch, D. G. Remick, S. L. Kunkel, R. M. Strieter, K. S. Guice, K. T. Oldham, and D. A. Campbell, Jr. 1990. The production of tumor necrosis factor alpha and the development of a pulmonary capillary injury following hepatic ischemia/reperfusion. Transplantation (Baltimore). 49:268272.

66. Colletti, L. M., D. G. Remick, G. D. Burtch, S. L. Kunkel, R. M. Strieter, and D. A. Campbell, Jr. 1990. Role of tumor necrosis factor- $\alpha$ in the pathophysiologic alterations after hepatic ischemia/reperfusion injury in the rat. J. Clin. Invest. 85:1936-1943. 